\title{
SEROPREVALENCE DETECTION OF ANTIBODIES OF COXIELLA BURNETII IN SHEEP, GOATS AND HUMAN IN SOME GOVERNORATES IN EGYPT
}

\author{
MONA M. SOBHY ${ }^{1}$; FATHI, A. ${ }^{2}$; IBRAHIM, E.M.M. ${ }^{3}$; ABOU-GAZIA, KH.A. ${ }^{1}$; \\ NOHA A. HELMY ${ }^{4}$ and ASMAA GAHLAN YOUSEEF ${ }^{5}$ \\ ${ }^{1}$ Reproductive Dis. Res. Dept. ARRI. ARC. Giza, Egypt. \\ ${ }^{2}$ Immunity Unit, ARRI, ARC. Giza, Egypt. \\ ${ }^{3}$ Sheep and Goats Res. Dept. APRI, ARC, Giza, Egypt. \\ ${ }^{4}$ Veterinary Sera and Vaccines Research Institute (VSVRI), ARC, Giza, Egypt. \\ ${ }^{5}$ Zoonosis Dept. Fac. of Vet Med. South Valley Univ.
}

Received: 26 September 2019; Accepted: 21 October 2019

\begin{abstract}
$Q$ fever is an important public health concern throughout the world and infection can lifelong illness in the host. It is caused by the bacterium Coxiella burnetii. The most frequent source of infection for human is domestic ruminants. This survey was carried out from April 2017 to May 2018 in some governorates in Egypt. A total of 1200 samples; 740 blood samples and 405 milk samples were collected from sheep and goat flocks also 55 serum samples were taken from workers of the farms. The overall seroprevalence of C.burnetii in serum and milk was detected in $25.5 \% \& 22.7 \%$ and $23.1 \%$ \& $23.7 \%$ in sheep and goats, respectively. While the seroprevalence of Coxiella burnetii in human in this study was $54.5 \%$. Sera and milk were screened using indirect fluorescent technique for detection of $\operatorname{IgM} \& \mathrm{IgG}$ and a Commercial Q fever antibody indirect ELISA test kits (IDEXX Laboratories, USA) to detect anti- C. burnetii IgG antibodies.
\end{abstract}

Key words: Q fever; Coxiella burnetii; Prevalence; Human; Sheep; Goats.

\section{INTRODUCTION}

$Q$ fever is a worldwide zoonotic disease caused by an obligate intracellular pathogen Coxiella burnetii (Tissot- Dupont and Raoult, 2008). C. burnetii has a wide range of animal reservoirs including rodents, ruminants, carnivores, lagomorphs, ticks and even birds and some wild animals (Sawyer et al., 1987 and Gardon et al., 2001). Ruminants were considered to be the main reservoirs for human infections (Muskens et al., 2007). Infected animals excrete $C$. burnetii in milk, urine, feces, and birth by products especially the placenta (Guatteo et al., 2006 and Parker et al., 2006). The primary mode of transmission is inhalation of pathogen contaminated aerosols from excreta of birth products (Komiya et al., 2003). All animal hosts for $\mathrm{Q}$ fever secrete $C$. burnetii in milk; thus, consumption of raw or unpasteurized milk or milk products could be a source of infection to humans (Maurin and Raoult 1999). Clinical manifestations of $Q$ fever in humans includes acute, chronic to fatigue syndrome. The main characteristic of $\mathrm{Q}$ fever is clinical

Corresponding author: Dr. Mona M. Sobhy

E-mail address: monagabr17@yahoo.com

Present address: Reproductive Dis. Res. Dept. ARRI. ARC. Giza, Egypt polymorphism. Acute $\mathrm{Q}$ fever is defined as primary infection with C. burnetii, and $<60 \%$ of infected patients may be asymptomatic (Anderson et al., 2013). However, acute Q fever can manifest as a flu-like and self-limited illness, and major clinical presentations of these patients are fever, headache, coughing, atypical pneumonia, hepatitis, myalgia, arthralgia, cardiac involvement, skin rash and neurologic signs, and $2 \%$ of patients with acute disease are hospitalized. The case fatality rate of acute $\mathrm{Q}$ fever is reported up to 1-2\% (Angelakis and Raoult 2010, Parker et al., 2006 and Frankel et al., 2011).

Approximately 5\% of acute Q fever cases go on to develop chronic Q fever. People may become chronically infected without having being previously diagnosed with acute disease and may manifest months or years after an acute infection (Fenollar et al., 2001). Chronic Q fever is accompanied with endocarditis, vascular infection, prosthetic joint arthritis, osteoarticular infection and lymphadenitis (Angelakis and Raoult 2010, Raoult 2012 and Eldin et al., 2017). Endocarditis and vascular infection caused by $Q$ fever are fatal if untreated (Anderson et al., 2013).

The aim of this study was to survey sheep, goats and human in some governorates in Egypt to estimate 
prevalence of C.burnetii infection in 4 seasons of the year.

\section{MATERIALS AND METHODS}

This survey was carried out from April 2017 to May 2018 in some governorates in Egypt. A total of 1200 samples; 740 blood samples and 405 milk samples were collected from sheep and goat flocks also 55 serum samples were taken from workers of the same farms. Sera were obtained by centrifugation at 1500 rpm for 10 minutes and kept at $-20^{\circ} \mathrm{C}$ until tested. Sera and milk samples were screened by using a commercial Q fever indirect fluorescent technique for detection of IgM \& IgG also applied ELISA test.

Table 1: Samples collected from sheep, goats and farm workers in some governorates in Egypt.

\begin{tabular}{ccccccc}
\hline \multirow{2}{*}{ locality } & No. of samples & Sheep samples & \multicolumn{2}{c}{ Goats samples } & Farm Workers \\
\cline { 3 - 6 } Gamples & & serum & milk & serum & milk & 5 \\
\hline Fayoum & $\mathbf{1 5 0}$ & 50 & 45 & 25 & 25 & 8 \\
\hline Beni Suef & $\mathbf{1 5 8}$ & 70 & 25 & 40 & 15 & 7 \\
\hline Menia & $\mathbf{1 1 7}$ & 40 & 15 & 30 & 25 & 8 \\
\hline Mansoura & $\mathbf{1 9 8}$ & 70 & 30 & 60 & 30 & 9 \\
\hline Sharkia & $\mathbf{1 0 9}$ & 40 & 20 & 25 & 15 & 8 \\
\hline Assuit & $\mathbf{1 7 8}$ & 60 & 40 & 45 & 25 & 5 \\
\hline Qena & $\mathbf{1 9 0}$ & 60 & 30 & 60 & 35 & 5 \\
\hline Total & $\mathbf{1 0 0}$ & 30 & 20 & 35 & 10 & 55 \\
\hline
\end{tabular}

Table 2: Samples from sheep, goats and farm workers in different season.

\begin{tabular}{ccccccc}
\hline \multirow{2}{*}{ Season } & No. of samples & \multicolumn{2}{c}{ Sheep samples } & \multicolumn{2}{c}{ Goats samples } & \multicolumn{2}{c}{$\begin{array}{c}\text { Farm Workers } \\
\text { samples }\end{array}$} \\
\cline { 3 - 6 } Spring & $\mathbf{3 0 8}$ & serum & milk & serum & milk & 13 \\
\hline Summer & $\mathbf{3 1 5}$ & 110 & 45 & 90 & 55 & 15 \\
\hline Autumn & $\mathbf{2 8 7}$ & 100 & 60 & 70 & 40 & 17 \\
\hline Winter & $\mathbf{2 9 0}$ & 90 & 50 & 95 & 45 & 10 \\
\hline Total & $\mathbf{1 2 0 0}$ & 420 & 225 & 320 & 180 & 55 \\
\hline
\end{tabular}

Indirect fluorescent technique: The detection of IgM and IgG antibodies in serum and milk was done by using commercial Kit's manufacturer VIRCELL*, (SPAIN) according to Soriano et al. (1993).

\section{ELISA test:}

Commercial Q fever antibody indirect ELISA test kits (IDEXX Laboratories, USA) were used to detect antiC. burnetii $\mathrm{IgG}$ antibodies. The sample optical densities (OD) were measured by a microplate ELISA reader (Biomed, USA) at $450 \mathrm{~nm}$ according to Schelling et al. (2003). 


\section{RESULTS}

Table 3: Seroprevalence of C. burnetii among sheep, goats and worker farms samples in some governorates in Egypt by ELISA test.

\begin{tabular}{|c|c|c|c|c|c|c|}
\hline \multirow{2}{*}{ locality } & \multirow{2}{*}{$\begin{array}{c}\text { No. of } \\
\text { samples }\end{array}$} & \multicolumn{2}{|c|}{ Sheep +ve samples } & \multicolumn{2}{|c|}{ Goats +ve samples } & \multirow{2}{*}{ +ve Farm Workers samples } \\
\hline & & serum & milk & serum & milk & \\
\hline \multirow{2}{*}{ Giza } & \multirow{2}{*}{150} & $10 / 50$ & $7 / 45$ & $9 / 25$ & $3 / 25$ & $3 / 5$ \\
\hline & & $20 \%$ & $15.5 \%$ & $36 \%$ & $12 \%$ & $60 \%$ \\
\hline \multirow{2}{*}{ Fayoum } & \multirow{2}{*}{158} & $18 / 70$ & $5 / 25$ & $8 / 40$ & $2 / 15$ & $5 / 8$ \\
\hline & & $25.7 \%$ & $20 \%$ & $20 \%$ & $13.3 \%$ & $62.5 \%$ \\
\hline \multirow{2}{*}{ Beni Suef } & \multirow{2}{*}{117} & $12 / 40$ & $3 / 15$ & $9 / 30$ & $5 / 25$ & $4 / 7$ \\
\hline & & $30 \%$ & $20 \%$ & $30 \%$ & $20 \%$ & $57.1 \%$ \\
\hline \multirow{2}{*}{ Menia } & \multirow{2}{*}{198} & $20 / 70$ & 9/30 & $12 / 60$ & $4 / 30$ & $4 / 8$ \\
\hline & & $28.5 \%$ & $30 \%$ & $20 \%$ & $13.3 \%$ & $50 \%$ \\
\hline \multirow{2}{*}{ Mansoura } & \multirow{2}{*}{109} & $12 / 40$ & $6 / 20$ & $9 / 25$ & $6 / 15$ & $5 / 9$ \\
\hline & & $30 \%$ & $30 \%$ & $36 \%$ & $40 \%$ & $55.5 \%$ \\
\hline \multirow{2}{*}{ Sharkia } & \multirow{2}{*}{178} & $15 / 60$ & $8 / 40$ & $11 / 45$ & $10 / 25$ & $4 / 8$ \\
\hline & & $25 \%$ & $20 \%$ & $24.4 \%$ & $40 \%$ & $50 \%$ \\
\hline \multirow{2}{*}{ Assuit } & \multirow{2}{*}{190} & $12 / 60$ & $7 / 30$ & $10 / 60$ & $7 / 35$ & $3 / 5$ \\
\hline & & $20 \%$ & $23.3 \%$ & $16.7 \%$ & $20 \%$ & $60 \%$ \\
\hline \multirow{2}{*}{ Qena } & \multirow{2}{*}{100} & $8 / 30$ & $6 / 20$ & $6 / 35$ & $2 / 10$ & $2 / 5$ \\
\hline & & $26.7 \%$ & $30 \%$ & $17.1 \%$ & $20 \%$ & $40 \%$ \\
\hline \multirow{2}{*}{ Total } & \multirow{2}{*}{1200} & $107 / 420$ & $51 / 225$ & $74 / 320$ & $39 / 180$ & $30 / 55$ \\
\hline & & $25.5 \%$ & $22.7 \%$ & $23.1 \%$ & $21.7 \%$ & $54.5 \%$ \\
\hline
\end{tabular}

Table 4: Positive cases for Q fever among examined sheep, goats and worker farms samples by ELISA test in relation to seasons.

\begin{tabular}{|c|c|c|c|c|c|c|c|}
\hline \multirow{2}{*}{ Season } & \multirow{2}{*}{$\begin{array}{c}\text { No. of } \\
\text { samples }\end{array}$} & \multirow{2}{*}{$\begin{array}{c}\text { No. of +ve } \\
\text { samples }\end{array}$} & \multicolumn{2}{|c|}{ Sheep samples } & \multicolumn{2}{|c|}{ Goats samples } & \\
\hline & & & serum & milk & serum & milk & \\
\hline \multirow{2}{*}{ Spring } & \multirow{2}{*}{308} & 70/308 & $28 / 120$ & $12 / 70$ & $17 / 65$ & $5 / 40$ & $8 / 13$ \\
\hline & & $22.7 \%$ & $23.3 \%$ & $17.1 \%$ & $26.1 \%$ & $12.5 \%$ & $61.5 \%$ \\
\hline \multirow{2}{*}{ Summer } & \multirow{2}{*}{315} & $82 / 315$ & $32 / 110$ & $12 / 45$ & $21 / 90$ & 9/55 & $8 / 15$ \\
\hline & & $26 \%$ & $29.1 \%$ & $26.7 \%$ & $23.3 \%$ & $16.4 \%$ & $53.3 \%$ \\
\hline \multirow{2}{*}{ Autumn } & \multirow{2}{*}{287} & $86 / 287$ & $27 / 100$ & $14 / 60$ & $20 / 70$ & $16 / 40$ & $9 / 17$ \\
\hline & & $29.9 \%$ & $27 \%$ & $23.3 \%$ & $28.6 \%$ & $40 \%$ & $52.9 \%$ \\
\hline \multirow{2}{*}{ Winter } & \multirow{2}{*}{290} & $63 / 290$ & $20 / 90$ & $13 / 50$ & $16 / 95$ & $9 / 45$ & $5 / 10$ \\
\hline & & $21.7 \%$ & $22.2 \%$ & $26 \%$ & $16.8 \%$ & $20 \%$ & $50 \%$ \\
\hline \multirow{2}{*}{ Total } & \multirow{2}{*}{1200} & $301 / 1200$ & $107 / 420$ & $51 / 225$ & $74 / 320$ & $39 / 180$ & $30 / 55$ \\
\hline & & $25.1 \%$ & $25.5 \%$ & $22.7 \%$ & $23.1 \%$ & $21.7 \%$ & $54.5 \%$ \\
\hline
\end{tabular}


Table 5: Seroprevalence of $C$. burnetii among sheep, goats and farm worker samples in some governorates by IFA test.

\begin{tabular}{|c|c|c|c|c|c|c|c|c|c|c|c|}
\hline \multirow{3}{*}{ locality } & \multirow{3}{*}{$\begin{array}{c}\text { No. of } \\
\text { samples }\end{array}$} & \multicolumn{4}{|c|}{ Sheep +ve samples } & \multicolumn{4}{|c|}{ Goats +ve samples } & \multirow{2}{*}{\multicolumn{2}{|c|}{$\begin{array}{l}\text { +ve farm } \\
\text { workers } \\
\text { samples } \\
\end{array}$}} \\
\hline & & \multicolumn{2}{|c|}{ serum } & \multicolumn{2}{|c|}{ milk } & \multicolumn{2}{|c|}{ serum } & \multicolumn{2}{|c|}{ milk } & & \\
\hline & & IgM & $\mathrm{IgG}$ & IgM & $\mathrm{IgG}$ & IgM & IgG & IgM & IgG & $\operatorname{IgM}$ & IgG \\
\hline Giza & 150 & $\begin{array}{l}3 / 50 \\
6 \% \\
\end{array}$ & $\begin{array}{l}6 / 50 \\
12 \% \\
\end{array}$ & $\begin{array}{r}2 / 45 \\
4.4 \% \\
\end{array}$ & $\begin{array}{c}5 / 45 \\
11.1 \% \\
\end{array}$ & $\begin{array}{l}3 / 25 \\
12 \% \\
\end{array}$ & \begin{tabular}{|l}
$5 / 25$ \\
$20 \%$ \\
\end{tabular} & $\begin{array}{l}/ 25 \\
4 \% \\
\end{array}$ & $\begin{array}{l}2 / 25 \\
8 \% \\
\end{array}$ & $\begin{array}{c}1 / 5 \\
20 \% \\
\end{array}$ & $\begin{array}{c}2 / 5 \\
40 \% \\
\end{array}$ \\
\hline Fayoum & 158 & $\begin{array}{c}4 / 70 \\
5.7 \% \\
\end{array}$ & $\begin{array}{c}12 / 70 \\
17.1 \% \\
\end{array}$ & $\begin{array}{l}/ 25 \\
8 \% \\
\end{array}$ & \begin{tabular}{|l|}
$3 / 25$ \\
$12 \%$ \\
\end{tabular} & $\begin{array}{l}2 / 40 \\
5 \% \\
\end{array}$ & $\begin{array}{c}5 / 40 \\
12.5 \% \\
\end{array}$ & $\mathbf{0}$ & $\begin{array}{c}2 / 15 \\
13.3 \% \\
\end{array}$ & $\begin{array}{c}1 / 8 \\
12.5 \% \\
\end{array}$ & $\begin{array}{c}4 / 8 \\
50 \% \\
\end{array}$ \\
\hline $\begin{array}{l}\text { Beni } \\
\text { Suef } \\
\end{array}$ & 117 & $\begin{array}{c}3 / 40 \\
7.5 \% \\
\end{array}$ & $\begin{array}{l}6 / 40 \\
15 \% \\
\end{array}$ & $\mathbf{0}$ & $\begin{array}{l}2 / 15 \\
8 \% \\
\end{array}$ & $\begin{array}{l}3 / 30 \\
10 \% \\
\end{array}$ & $\begin{array}{c}5 / 30 \\
16.6 \% \\
\end{array}$ & $\begin{array}{l}2 / 25 \\
8 \% \\
\end{array}$ & $\begin{array}{l}2 / 25 \\
8 \% \\
\end{array}$ & $\begin{array}{c}2 / 7 \\
28.6 \% \\
\end{array}$ & $\begin{array}{c}3 / 7 \\
\mathbf{4 2 . 8 \%} \\
\end{array}$ \\
\hline Menia & 198 & $\begin{array}{r}5 / 70 \\
7.1 \% \\
\end{array}$ & $\begin{array}{l}14 / 70 \\
20 \% \\
\end{array}$ & \begin{tabular}{r|}
$2 / 30$ \\
$6.7 \%$ \\
\end{tabular} & $\begin{array}{c}5 / 30 \\
16.7 \% \\
\end{array}$ & $\begin{array}{l}4 / 60 \\
6.7 \% \\
\end{array}$ & $\begin{array}{c}7 / 60 \\
11.7 \% \\
\end{array}$ & $\begin{array}{c}2 / 30 \\
6.7 \% \\
\end{array}$ & $\begin{array}{l}2 / 30 \\
6.7 \% \\
\end{array}$ & $\begin{array}{c}1 / 8 \\
12.5 \% \\
\end{array}$ & $\begin{array}{c}2 / 8 \\
25 \% \\
\end{array}$ \\
\hline Mansoura & 109 & $\begin{array}{r}3 / 40 \\
7.5 \% \\
\end{array}$ & $\begin{array}{l}8 / 40 \\
20 \% \\
\end{array}$ & $\begin{array}{l}2 / 20 \\
5 \% \\
\end{array}$ & $\begin{array}{l}3 / 20 \\
15 \% \\
\end{array}$ & $\begin{array}{l}2 / 25 \\
8 \% \\
\end{array}$ & $\begin{array}{l}4 / 25 \\
16 \% \\
\end{array}$ & \begin{tabular}{|l|}
$1 / 15$ \\
$6.7 \%$ \\
\end{tabular} & $\begin{array}{c}2 / 15 \\
13.3 \% \\
\end{array}$ & $\begin{array}{c}2 / 9 \\
22.2 \% \\
\end{array}$ & $\begin{array}{c}4 / 9 \\
44.4 \% \\
\end{array}$ \\
\hline Sharkia & 178 & $\begin{array}{l}4 / 60 \\
6.7 \% \\
\end{array}$ & $\begin{array}{c}10 / 60 \\
16.7 \% \\
\end{array}$ & $\begin{array}{r}1 / 40 \\
2.5 \% \\
\end{array}$ & $\begin{array}{c}5 / 40 \\
12.5 \% \\
\end{array}$ & \begin{tabular}{|l|}
$4 / 45$ \\
$8.9 \%$ \\
\end{tabular} & $\begin{array}{c}6 / 45 \\
13.3 \% \\
\end{array}$ & $\begin{array}{l}3 / 25 \\
12 \% \\
\end{array}$ & $\begin{array}{l}4 / 25 \\
16 \% \\
\end{array}$ & 0 & $\begin{array}{c}4 / 8 \\
50 \% \\
\end{array}$ \\
\hline Assuit & 190 & $\begin{array}{l}4 / 60 \\
6.7 \% \\
\end{array}$ & $\begin{array}{r}6 / 60 \\
10 \% \\
\end{array}$ & $\begin{array}{r}2 / 30 \\
6.7 \% \\
\end{array}$ & $\begin{array}{l}3 / 30 \\
10 \% \\
\end{array}$ & $\begin{array}{r}2 / 60 \\
3.3 \% \\
\end{array}$ & $\begin{array}{r}6 / 60 \\
10 \% \\
\end{array}$ & $\begin{array}{r}2 / 35 \\
5.7 \% \\
\end{array}$ & $\begin{array}{c}4 / 35 \\
11.4 \% \\
\end{array}$ & $\begin{array}{r}1 / 5 \\
20 \% \\
\end{array}$ & $\begin{array}{c}3 / 5 \\
60 \% \\
\end{array}$ \\
\hline Qena & 100 & $\begin{array}{l}2 / 30 \\
6.7 \% \\
\end{array}$ & $\begin{array}{c}4 / 30 \\
13.3 \% \\
\end{array}$ & $\begin{array}{l}1 / 20 \\
5 \%\end{array}$ & $\begin{array}{l}3 / 20 \\
15 \% \\
\end{array}$ & $\begin{array}{r}1 / 35 \\
2.8 \% \\
\end{array}$ & $\begin{array}{c}4 / 35 \\
11.4 \% \\
\end{array}$ & $\begin{array}{l}1 / 10 \\
10 \% \\
\end{array}$ & $\begin{array}{r}2 / 10 \\
20 \% \\
\end{array}$ & $\begin{array}{c}1 / 5 \\
20 \%\end{array}$ & $\begin{array}{c}2 / 5 \\
40 \% \\
\end{array}$ \\
\hline Total & 1200 & $\begin{array}{c}28 / 420 \\
6.7 \% \\
\end{array}$ & $\begin{array}{l}66 / 420 \\
15.7 \% \\
\end{array}$ & $\begin{array}{l}10 / 225 \\
4.4 \% \\
\end{array}$ & $\begin{array}{l}24 / 225 \\
10.7 \% \\
\end{array}$ & $\begin{array}{l}18 / 320 \\
5.6 \% \\
\end{array}$ & \begin{tabular}{|l|}
$42 / 320$ \\
$13.1 \%$ \\
\end{tabular} & $\begin{array}{l}12 / 180 \\
6.7 \% \\
\end{array}$ & $\begin{array}{l}20 / 180 \\
11.1 \% \\
\end{array}$ & $\begin{array}{c}9 / 55 \\
16.4 \% \\
\end{array}$ & $\begin{array}{r}24 / 55 \\
43.6 \% \\
\end{array}$ \\
\hline
\end{tabular}

\section{DISCUSSION}

In this study the overall occurrence of Coxiella burnetii in serum and milk was detected in $(25.5 \%$ \& $22.7 \%)$ and $(23.1 \% \& 23.7 \%)$ identified by ELISA in sheep and goats respectively (Table 3). Lower percentages of Coxiella burnetii specific antibodies were detected in $8.9 \%$ of sheep and $6.8 \%$ of goats' blood samples, respectively by Klemmer et al. (2018). Also Mohammed et al. (2014) reported that the percentage of Coxiella burnetii in goat's blood samples was $5.3 \%$, but milk samples obtained from goats showed no positive samples, while none of the samples collected from sheep revealed positive for C. burnetii. However the overall seropositivity of $\mathrm{Q}$ fever detected in sheep and goats $(25.5 \%$ \& $23.1 \%)$ was in agreement with that reported $(24.7 \%$ \& $24.2 \%$ ) in Iran and Sudan by Hussein et al. (2012) and Mobarez et al. (2017), respectively.

In contrast, a study on farm animals from the Giza, Cairo and Fayoum governorates showed remarkably high seroprevalence in sheep $32.7 \%$ but seroprevalence in goats was $(23.3 \%)$ which agreed with Nahed and Abdel-Moein (2012). This difference could be explained by the high small ruminant density of this rural region and the fact that infected small ruminants may shed bacteria in high numbers (Dijkstra et al., 2012 and Abdel- Moein and Hamza, 2017).

Klemmer et al. (2018) examined sheep and detected $C$. burnetii specific antibodies in $8.3 \%$, $16.7 \%, 8.3 \%, 0 \%, 25 \%, 0 \%$ and $11.1 \%$ from Menia, Sharkia, Qena, Giza, Fayoum, Beni Suef and Assuit governorates. Their results are in agreement with the data of this study corresponding to $25.7 \%$ in Fayoum governorate. But their results are lower than the result of this study corresponding to $28.6 \%, 25 \%, 26.7 \%$, 20\%, 30\% and 20\% in Menia, Sharkia, Qena, Giza, Beni Suef and Assuit governorates. The high seroprevalence of $\mathrm{Q}$ fever among sheep and goats highlighted the potential role which may be played by these animals in the epidemiology of $\mathrm{Q}$ fever which being important reservoirs for $C$. burnetii and its zoonotic implications in Egypt (Nahed and AbdelMoein, 2012). However Klemmer et al. (2018) failed to detect C. Burnetii specific antibodies in goats from Sharkia, Qena, Giza, Assuit governorates, while C. Burnetii was detected in goats from Menia and Beni Suef in $8.3 \%$ and $12.5 \%$, respectively. The differences in prevalence rates may be attributed to local ecological factors, type of management and practices, flock size... etc. that might influence the transmission rates and infection with $C$. burnetii (Hussein et al., 2017).

The seroprevalence of Coxiella burnetii in farm workers in this study was $54.5 \%$ which is greater than that obtained by Mazyad and Hafez (2007) (3.3\%), Botros et al. (1995) who found a seroprevalence $25 \%$ among cattle workers in Egypt, Nahed and AbdelMoein (2012) who recorded the seroprevalence $16.3 \%$ in the examined persons and Vilibic-Cavlek et al. (2012) detect IgG antibodies of Coxiella burnetii in Sera from $27.5 \%$ patients. Human seroprevalence was reported from $1-32 \%$ in Africa (Vanderburg et al., 2014). Human seroprevalence of Q fever were reported 3 to $35.8 \%$ in Kenya (Njeru et al., 2016), 12.3-32\% in Turkey (Kilic et al., 2008 and Gozalan et al., 2010). The differences between 
countries could be due to varieties in ecologic, social, cultural, behavioral and economic conditions and also levels of animal's infections, which affect the exposures of people in each region of the world (Mobarez et al., 2017). Also these differences can be attributed to the variations in the proportion of population involved in farming activities (VilibicCavlek et al., 2012).

The IgG of Q fever reported in this study by IFA test in sheep $(15.7 \%)$ was higher than in goats $(13.1 \%)$ in serum but was reverse in goats $(11.1 \%)$ higher than in sheep $(10.7 \%)$. While, IgG in farm workers was recorded $43.6 \%$ (Table, 5). Transmission of $C$. burnetii through milk is also possible (Kruszewska et al., 1997). Consumption of raw or unpasteurized milk or milk products could be a source of infection milk borne pathogens (Hussien et al., 2017).

Similar to other studies, the present results showed that the prevalence of $C$. burnetii antibodies tends to increase in summer and autumn months. A majority of cases were recorded in summer and autumn (Vilibic-Cavlek et al., 2012). Also data from the European Union have shown a seasonal pattern of Q fever with more cases reported during the summer months (Coulombier, 2010).

\section{CONCLUSION}

It is concluded that consumption of raw milk and milk products from all domestic species should be avoided to reduce the risk of infection with Q fever as well as with other milk and milk products borne pathogens. The IFA and ELISA tests proved to be sensitive and specific methods for the detection of Coxiella antibodies. Both assays have a high positive and negative predictor value, ensuring a high correlation with previous exposure to Coxiella.

\section{REFERENCES}

Abdel-Moein, K.A. and Hamza, D.A. (2017): The burden of Coxiella burnetii among aborted dairy animals in Egypt and its public health implications. Acta tropica. 166: 92-5.

Anderson, A.; Bijlmer, H.; Fournier, P.E.; Graves, S. and Hartzell, J. (2013): Diagnosis and management of $\mathrm{Q}$ fever-United States, recommendations from $\mathrm{CDC}$ and the $\mathrm{Q}$ Fever Working Group. MMWR Recomm Rep 62: 130.

Angelakis, E. and Raoult, D. (2010): Q fever. Veterinary microbiology 140: 297-309.

Botros, B.A.; Soliman, A.K.; Salib, A.W.; Olson, J.; Hibbs, R.G.; Williams, J.C.; Darwish, M.; ElTegani, A. and Watts, D.M. (1995): Coxiella burntii antibody prevalences among human populations in Northeast Africa determined by enzyme immunoassay. J Trop Med Hyg. 98: 173-178.

Coulombier, D. (2010): Query fever: an opportunity to understand the disease better. Euro Surveill. 15:19526

Dijkstra, F.; Van Der Hoek, W.; Wijers, N.; Schimmer, B.; Rietveld, A. and Wijkmans, C.J. (2012): The 2007-2010 Q fever epidemics in The Netherlands: characteristics of notified acute $\mathrm{Q}$ fever patients and the association with dairy goat farming. FEMS immunology and medical microbiology. 64(1): 3-12.

Eldin, C.; Mélenotte, C.; Mediannikov, O.; Ghigo, E. and Million, M. (2017): From Q fever to Coxiella burnetii infection: a paradigm change. Clinical Microbiology Reviews 30: 115-190.

Fenollar, F.; Fournier, P-E.; Carrieri, M.P.; Habib, G. and Messana, T. (2001): Risks factors and prevention of $\mathrm{Q}$ fever endocarditis. Clinical Infectious Diseases 33: 312-316.

Frankel, D.; Richet, H.; Renvoisé, A. and Raoult, D. (2011): Q fever in France, 1985-2009. Emerg Infect Dis 17: 350-356.

Gardon, J.; Héraud, J.M.; Laventure, S.; Ladam, A.; Capot, P.; Fouquet, E. Favre, J.; Weber, S. Hommel, D.; Hulin, A.; Couratte, Y. and Talarmin, A. (2001): Suburban transmission of $\mathrm{Q}$ fever in French Guiana: evidence of a wild reservoir. J Infect Dis.; 184: 278-284.

Gozalan, A.; Rolain, J.; Ertek, M.; Angelakis, E. and Coplu, N. (2010): Seroprevalence of Q fever in a district located in the west Black Sea region of Turkey. European journal of clinical microbiology \& infectious diseases 29: 465469.

Guatteo, R.; Beaudeau, F.; Berri, M.; Rodolakis, A.; Jolyc, A. and Seegers, H. (2006): Shedding routes of Coxiella burnetii in dairy cows: implications for detection and control," Veterinary Research, vol. 37, no. 6, pp. 827-833.

Hussien, M.; ElFahal, A.; Enan, K.; Taha, K.; Mohammed, M. and Salih, D. (2012): Seroprevalence of $\mathrm{Q}$ fever in goats in the Sudan. Veterinary World. 5 (7): 394.

Hussien, M.O.; Enan, K.A.; Hassan Alfaki, S.; Alhibir Gafar, R. and Mohamed Taha, K. (2017): Seroprevalence of Coxiella burnetii in Dairy Cattle and Camel in Sudan, Int J Infect. 4(3): e42945.

Kilic, S.; Yilmaz, G.R.; Komiya, T.; Kurtoglu, Y. and Karakoc, E.A. (2008): Prevalence of Coxiella burnetii antibodies in blood donors in Ankara, Central Anatolia, Turkey. New Microbiol 31: 527-534.

Klemmer, J.; Njeru, J.; Emam, A. El-Sayed, A.; Moawad, A.A. and Henning, K. (2018): Q fever in Egypt: Epidemiological survey of Coxiella burnetii specific antibodies in cattle, 
buffaloes, sheep, goats and camels. PLoS ONE 13(2): e0192188.

Komiya, T.; Sadamasu, K.; Toriniwa, H.; Kato, K., Arashima, Y.; Fukushi, H.; Hirai, K. and Arakawa, Y. (2003): Epidemiological survey on the route of Coxiella burnetii infection in an animal hospital. J Infect Chemother. 2003 Jun; 9(2): 151-5.

Kruszewska, D. and Tylewska-Wierzbanowska, S. (1997): Isolation of Coxiella burnetii From bull semen. Res Vet Sci. 1997; 62(3):299-300.

Maurin, M. and Raoult, D. (1999): Q fever. Clin Microbiol Rev; 12(4): 518 -53.

Mazyad, S.A. and Hafez, A.O. (2007): Q fever (Coxiella burnetii) among man and farm animals in North Sina. J Egypt Soc Parasitol.; 37: $135-42$.

Mobarez, A.M.; Amiri, F.B. and Ismailia, S. (2017): Seroprevalence of $\mathrm{Q}$ fever among human and animal in Iran; A systematic review and metaanalysis PLoS Negl Trop Dis.; 11(4): $\mathrm{e} 0005521$.

Mohammed, O.B.; Jarelnabi, A.A.; Aljumaah, R.S.; Alshaikh, M.A.; Bakhiet, A.M.; Omer, S.A. Alagaili, A.N. and Hussein, M.F. (2014): Coxiella burnetii, the causative agent of $\mathrm{Q}$ fever in Saudi Arabia: molecular detection from camel and other domestic livestock. Asian Pacific Journal of Tropical Medicine. 715-719.

Muskens, J.; Mars, M.H. and Franken, P. (2007): Q fever: an overview. Tijdschr Diergeneeskd; 132: 912-917.

Nahed, H.G. and Abdel-Moein, K.A. (2012): Seroprevalence of Coxiella burnetii antibodies among farm animals and human contacts in Egypt. Journal of American Science. 8(3): 619-21.
Njeru, J.; Henning, K.; Pletz, M.; Heller, R. and Neubauer, H. (2016): Q fever is an old and neglected zoonotic disease in Kenya: a systematic review. BMC public health 16: 1 .

Parker, N.R.; Barralet, J.H. and Bell, A.M. (2006): Q fever. The Lancet 367: 679-688.

Raoult, D. (2012): Chronic Q fever: expert opinion versus literature analysis and consensus. Journal of Infection 65: 102-108.

Sawyer, L.A.; Fishbein, D.B. and McDade, J.E. (1987): Q fever: current concepts. Rev. Infect. Dis.; 9: 935 - 946.

Schelling, E.; Diguimbaye, C.; Daoud, S.; Nicolet, J.; Boerlin, P.; Tanner, M. and Zinsstag, J. (2003): Brucellosis and Q-fever seroprevalence of nomadic pastoralists and their livestock in Chad._Prev Vet Med. 2003 Dec 12;61(4): 279-93.

Soriano, F.; Camacho, M.T.; Ponte, C. and Gomez, $P$. (1993): Serological differentiation between acute (late control) and endocarditis Q fever. J Clin Pathol 46:411-4.

Tissot-Dupont, H. and Raoult, D. (2008): Q fever. Infect Dis Clin North Am. 22: 505-514.

Vanderburg, S.; Rubach, M.P.; Halliday, J.E.; Cleaveland, S. and Reddy, E.A. (2014): Epidemiology of Coxiella burnetii infection in Africa: a One Health systematic review. PLoS Negl Trop Dis 8: e2787.

Vilibic-Cavlek, T.; Kucinar, J; Ljubin-Sternak, S.; Kolaric, B.; Kaic, B.; Lazaric-Stefanovic, L.; Hunjak, B. and Mlinaric-Galinovic, $\quad G$. (2012): Prevalence of Coxiella burnetii Antibodies Among Febrile Patients in Croatia, 2008-2010. Vector Borne Zoonotic Dis. Apr; 12(4): 293-296.

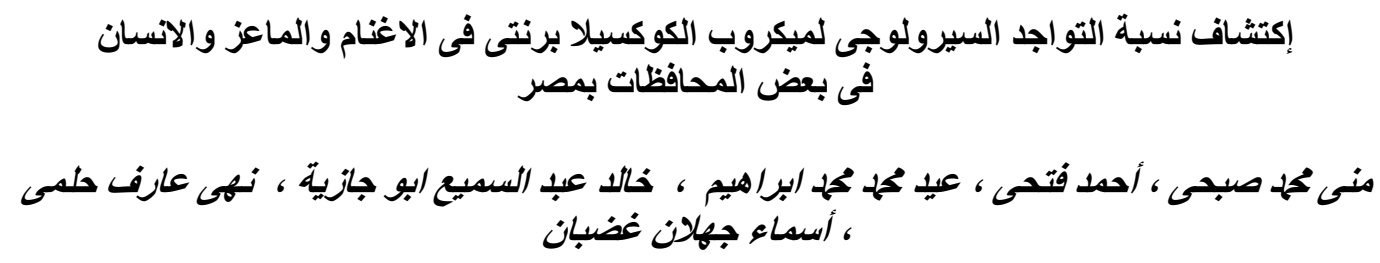

E-mail: monagabr17@yahoo.com

Assiut University web-site: www.aun.edu.eg

تعتبر حمى المجهولة أحد الامر اض الهامة التى تؤثر على الصحة العامة في جميع أنحاء العالم ، ويمكن الإصابة بالعدوى للمصاب

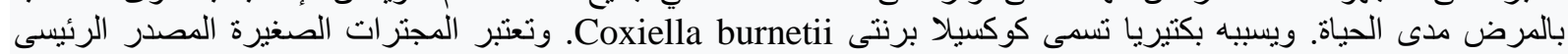

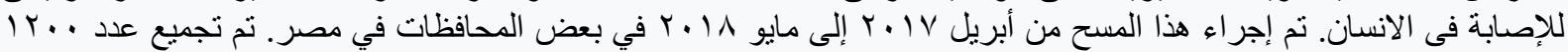

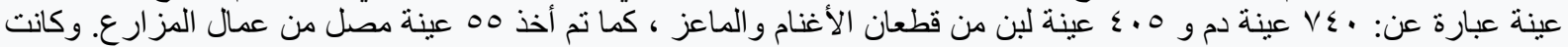

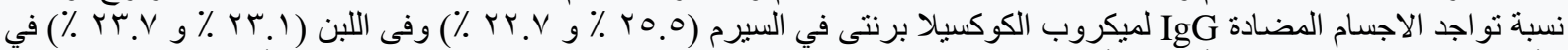

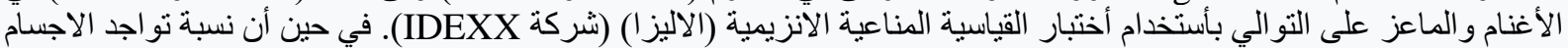

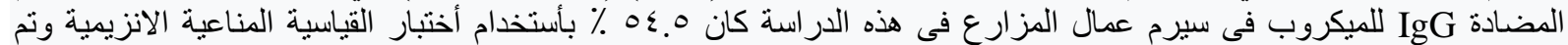

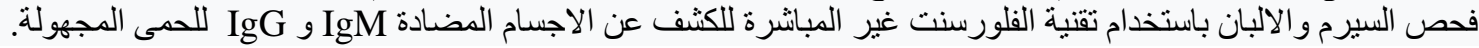

